\title{
PHYSICAL PROPERTIES OF SAND PARTS PRODUCED USING A VOXELJET VX1000 THREE- DIMENSIONAL PRINTER
}

\author{
K. Nyembwe ${ }^{1 *}$, M. Mashila ${ }^{2}$, P.J.M. van Tonder ${ }^{3}$, D.J. de Beer ${ }^{4}$ \& E. Gonya ${ }^{1}$
}

\section{ARTICLE INFO}

\section{Article details}

Presented at the $17^{\text {th }}$ annual

international conference of the Rapid

Product Development Association of

South Africa (RAPDASA), held from 2-4

November 2016 in Vanderbijlpark, South Africa

Available online

11 Nov 2016

\section{Contact details}

Corresponding author

dnyembwe@uj.ac.za

\section{Author affiliations}

1 Department of Metallurgy,

University of Johannesburg, South Africa

2 Metal Casting Technology Station, University of Johannesburg, South Africa

3 Technology Transfer and Innovation, Vaal University of Technology, South Africa

4 Technology Transfer and Innovation Support, North-West University, Potchefstroom Campus, South Africa

DOI

http://dx.doi.org/10.7166/27-3-1661

\section{ABSTRACT}

Successful case studies of metal casting applications using sand moulds and cores produced by additive manufacturing (AM) processes have been widely reported in the literature. The layeredbased manufacturing process has revolutionised traditional sand moulding methods. This is essentially due to the numerous advantages of $A M$, including the reduction of design lead time and the ability to manufacture objects with complex geometry in a rapid turnaround time. Locally-available $A M$ processes that are capable of producing sand moulds and cores include laser sintering (LS) and three-dimensional printing (3DP), with the latter $A M$ process growing in dominance over the former. However, a better understanding of the properties of parts produced by $A M$ processes is required in order for the processes to be fully adopted by the foundry industry. Crucial characteristics of 3DP sand parts related to strength, dimensional accuracy, and hardness are not wellknown in terms of their magnitude and in comparison with conventionally-moulded sand parts. In this investigation, the physical properties of test specimens produced under standard manufacturing conditions, using a Voxeljet VX1000 machine, were assessed for bend and tensile strength, hardness, friability, and surface finish. The physical properties of the 3DP test specimens were then compared with the properties of laboratory handrammed test specimens. The results of the investigation suggest that the properties of AM-fabricated sand parts are inferior to sand parts produced by conventional moulding processes.

\section{OPSOMMING}

Gevallestudies van metaalgiettoepassings, wat van sand gietvorms en kerns gebruik maak wat met toevoegingsvervaardiging vervaardig word, is al volop gepubliseer. Die laag-gebaseerde vervaardigingsproses het die tradisionele sandgietvorm metodes totaal hervorm. Dit is hoofsaaklik as gevolg van die talryke voordele van toevoegings-vervaardiging. Dit sluit in die verkorting van die ontwerpleityd en die vermoë om ingewikkelde geometrieë in 'n vinnige omkeertyd te vervaardig. ' $n$ Beter verstaan van die eienskappe van die onderdele, wat met toevoegingsvervaardigingtegnieke produseer word, is egter nodig voordat dit deur die gietbedryf aanvaar gaan word. Kritiese eienskappe van driedimensioneelgedrukte onderdele wat nie alombekend is nie is onder andere die sterkte, dimensionele akkuraatheid en hardheid. Die fisiese eienskappe van toetsmonsters is ondersoek vir buig- en treksterkte, hardheid, buigbaarheid, brosheid en oppervlakafwerking. Die fisiese eienskappe van die toetsmonsters is vergelyk met die eienskappe van laboratorium, handgekompakteerde monsters. Die resultate toon dat die toevoegingsvervaardiging monsters se eienskappe slegter as die van konvensioneel gegiete monsters is. 
The direct fabrication of foundry moulds and cores is one of the growing applications of additive manufacturing (AM) to sand casting technology [1]. This approach of rapid sand casting has somehow superseded the previous applications that essentially consist of $\mathrm{AM}$-fabricated pattern and core boxes [2]. In the near future, these tools will possibly no longer be required in the casting production process.

Improved and cost-effective AM processes mainly based on three-dimensional printing (3DP) have replaced older processes such as laser sintering (LS) and fused deposition modelling (FDM) for the direct production of sand moulds and cores $([3,4])$. Relatively recent 3DP technologies for rapid sand casting include ZCast [5], EXOne [6], and Voxeljet [7]; these are some of the most visible examples on the market.

Numerous successful case studies of the production of castings using sand moulds or cores produced by 3DP processes have been reported in the literature $[2,8]$. Attempts to replace conventional moulding machines by 3DP equipment for the industrial production of automotive castings is also being mentioned more often $[2,4,9]$. Continued developments in rapid sand casting will require a better understanding of the properties of parts produced by $\mathrm{AM}$ processes in order for these processes to be fully adopted by the local foundry industry.

Crucial characteristics of sand moulds and cores include strength, permeability, dimensional accuracy, and collapsibility, and are well-detailed in metal casting handbooks [10,11]. Strength generally expressed in terms of tensile and bend strength - is required to ensure that the moulds and cores will withstand handling operations and metallo-static pressure during casting. Hardness expresses the resistance to penetration, and is necessary to prevent mould wall movement and core distortion. Friability is the resistance to mould or core surface erosion during the pouring of the metal.

Few investigative studies have been carried out on the characteristics of moulds and cores produced by $A M$ processes and their possible effects on metal castings [12-15]. One such study [12] analysed the tensile strength and permeability of baked samples produced by the ZCast process. A mathematical model was then developed that could predict these properties as a function of the temperature and time of baking of the printed moulds. Snelling and his colleagues have investigated in detail the properties of ZCast moulds using differents types of powders [13] and binders [14]. The effects of these moulding materials on the casting properties in terms of surface roughness, density, hardness, and porosity were also assessed. From these studies, several recommendations were made on the performance of commercially-available raw materials. The properties of ZCast sand parts were also the focus of a study by Bassoli and Atzeni [15], who dealt with the mechanical optimisation and tolerance calculation of the ZCast process by varying the curing temperature.

The present investigation contributes to the body of knowledge on the properties of AM-fabricated sand parts by specifically looking at the ones produced using the Voxeljet technology. The characteristics of these sand parts are also compared with those of laboratory parts produced by conventional moulding methods involving hand-ramming (HR).

\section{EXPERIMENTAL PROCEDURES}

In this study, the properties of sand test specimens printed on a Voxeljet VX 1000 were determined and compared with those of sand test specimens produced in a laboratory using conventional HR methods, following the procedures of the American Foundry Society (AFS) [11]. The raw materials used, the types of sand test specimen, the experimental parameters, and the conditions are described in the sections below.

\subsection{Raw materials}

The Voxeljet VX 1000 raw materials include silica sand, recycled silica sand, and furfuryl alcoholbased binder, also known as furan resin. The silica sand used on the printer is pre-coated with sulphonic acid as a catalyst. The silica sand and the furan resin were imported raw materials recommended by the 3DP equipment's manufacturer. The recycled sand is the excess contaminated 
sand collected during part removal after build completion. The same raw materials were also used for the production of test specimens in the laboratory.

\subsection{Sand test specimens}

Three types of sand test specimens were produced by AM on the Voxeljet VX 1000 and by HR in the laboratory, including tensile, bend, and compression specimens. The drawings and dimensions of test specimens conform to the AFS specifications [11]. These test specimens were then used to determine various properties of the sand parts, namely tensile and bend strengths, friability, hardness (Scale B), surface finish, and density. Appropriate foundry sand testing equipment and corresponding testing instructions from Ridsdale and Ridsdale Dietert [16] were used to determine the strength, hardness, and friability. The surface finish was assessed with the help of a TIME instrument model TR 110 [17]. Finally, a laboratory precision scale was used to determine the mass of the test specimens.

\subsection{Experimental parameters and conditions}

Sand test specimens produced by $A M$ and $H R$ in the laboratory were prepared using the standard operating conditions of the Voxeljet VX 1000, which consisted of a sand mix of 60 per cent virgin silica sand and 40 per cent recycled sand. The addition of furfuryl alcohol-based binder was kept constant at 1 per cent. For comparison reasons, an additional batch of test specimens was produced by HR with 1.5 per cent binder added.

For the laboratory test specimen, silica sand and furan resin were safely mixed in a $5 \mathrm{~kg}$ laboratory mixer for five minutes before being rammed into the appropriate test specimen wooden moulds [11].

Sand specimens were tested in both uncured and cured conditions. The uncured condition corresponds to the green state of the part before heating after 24 hours self-setting of the sample at room temperature. The cured state relates to the post-processing of the sand specimen by heating in an air-ventilated oven at $110{ }^{\circ} \mathrm{C}$ for two hours as per Voxeljet guidelines. The specimens were removed from the oven and allowed to cool to room temperature.

From the previous processes, there were three manufacturing modalities: AM, HR (1 per cent binder addition), and HR (1.5 per cent binder addition). For each modality, three types of sand test specimens were produced: tensile, bend, and compression. For each case, five sand samples were tested and the average reported.

\section{RESULTS AND DISCUSSION}

\subsection{Tensile and bend strength}

Figure 1 shows the strength test results of sand specimens produced by $A M$ and $H R$ in the uncured and cured conditions. In general, AM specimens (blue bars) have lower tensile and bend strengths than laboratory specimens (red bars) produced by HR for the same addition of binder (1 per cent). It was found that for uncured conditions, tensile and bend strengths for HR were 29.31 per cent and 15.70 per cent higher than that of $A M$ respectively. Under cured conditions, however, the tensile strength for both HR and AM was the same, while the bend strength for HR was 12.41 per cent higher than that of $A M$.

It can also be seen from Figure 1 that heat-curing improves the tensile and bend strengths of specimens. Increases of 90 per cent and 80 per cent were obtained for the tensile and bend strengths respectively in the case of heat curing when compared with the uncured conditions for the 3DP samples. Similar increases were noted for the HR samples. This is due to the effect of heat on the speed of the self-setting chemical reaction of furan resin, which meant that it quickly reached the maximum strength [10].

The tensile and bend strengths achieved for the heat-cured $A M$ specimens were found to be higher than the strengths of uncured HR specimens, irrespective of the binder addition. This explains why heat-curing is necessary for $\mathrm{AM}$ parts to compensate for the poor compaction and to produce parts that are as strong as HR parts for the same level of binder addition. 


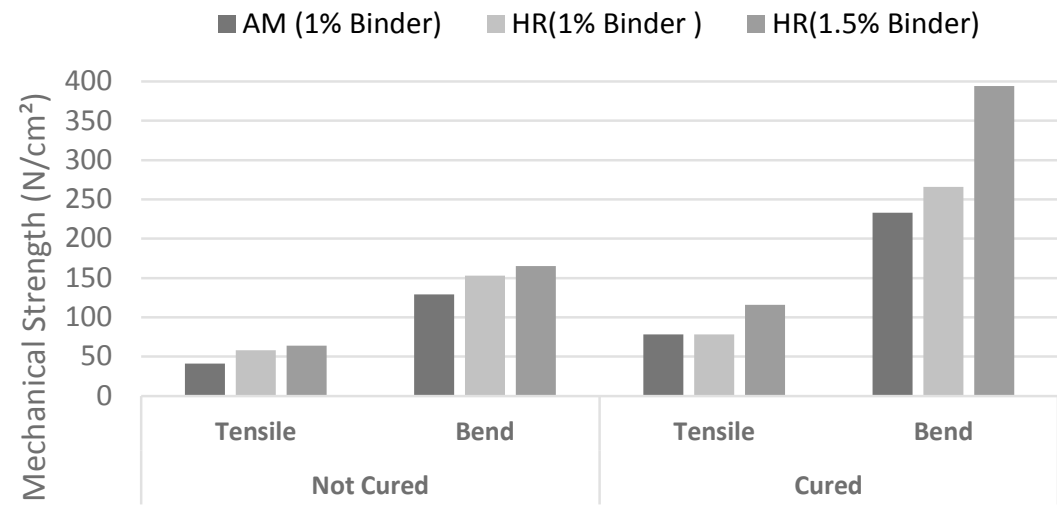

Figure 1: Tensile and bend strengths of sand specimens

\subsection{Hardness}

Figure 2 shows the hardness test results of sand specimens produced by AM and HR in the uncured and cured conditions. The hardness appears to remain within a very close range (between 93 and 96) for $A M$ and HR specimens. A difference of three on the hardness scale $B$ is practically insignificant. There is no effect from the sand specimen production method, the post-processing of specimen by heating, and the increase of resin addition on the hardness of samples. It is possible that the sand samples had already reached the maximum hardness after 24 hours of self-setting in the green state.

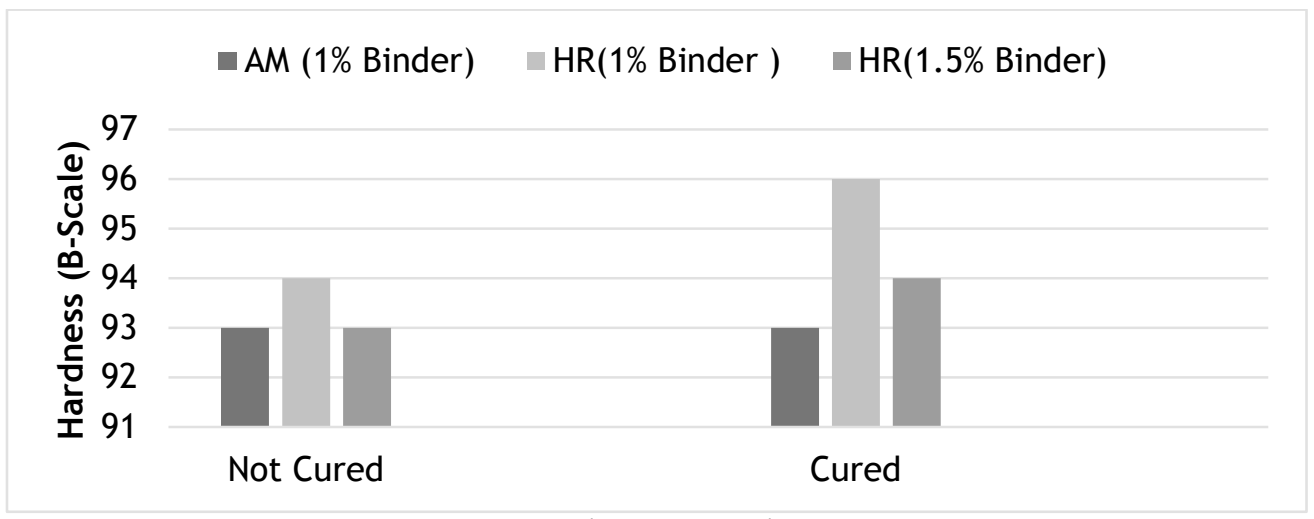

Figure 2: Hardness of sand specimens

\subsection{Friability}

Figure 3 illustrates the friability test results obtained during the experimental work. Lower friability values are preferred. In the uncured condition, the friability of $A M$ specimens (blue bar) is higher than for HR specimens (red bar) with the same amount of binder (1 per cent), but lower than HR specimens with a higher addition of resin ( 1.5 per cent). However, in the cured condition, the friability of $A M$ specimens is equal to the one of HR specimens with 1 per cent and 1.5 per cent resin addition. A final friability of samples after heating measured at 16 per cent.

It is important to note the extent of the improvement in friability after heat-curing $A M$ samples by 54 per cent. The friability also increased for HR samples after curing by 45 per cent and 55 per cent respectively for 1 per cent and 1.5 per cent addition of furan resin. 


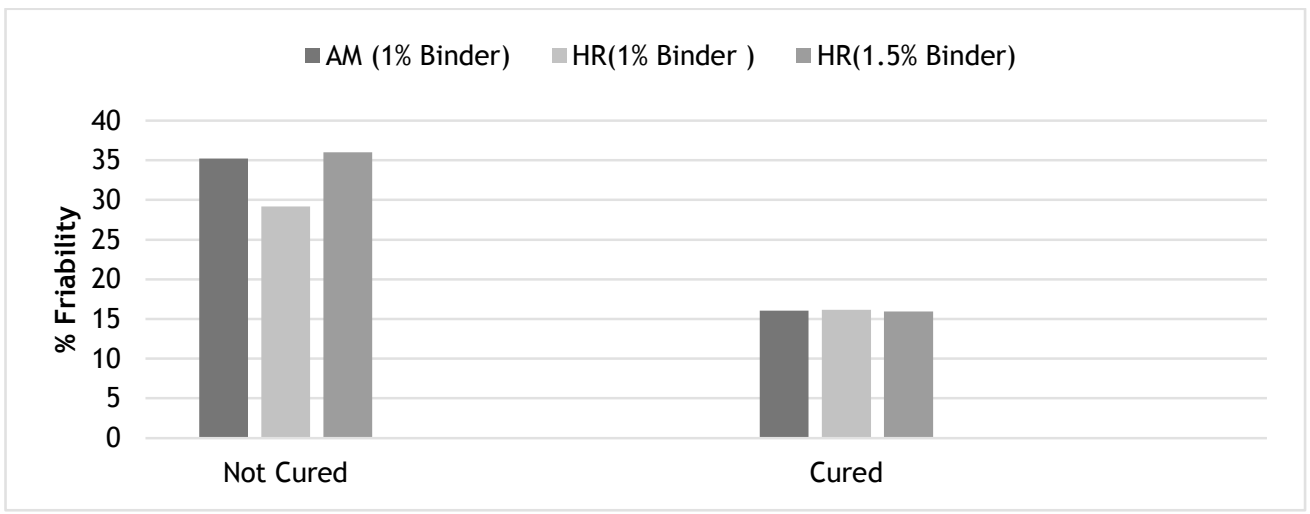

Figure 3: Friability of sand specimens

\subsection{Surface finish}

Figure 4 shows the results of surface finish tests conducted on the samples. A higher value of $R_{z}$ indicates poor surface finish and vice versa. It can be seen that $A M$ sand specimens have an inferior surface finish to that of HR sand specimens in both the uncured and cured conditions. The surface finish of sand specimens is primarily a function of the sand's fineness. However, in this instance, the compaction of HR specimens could possibly explain the better surface finish of the HR sand samples.

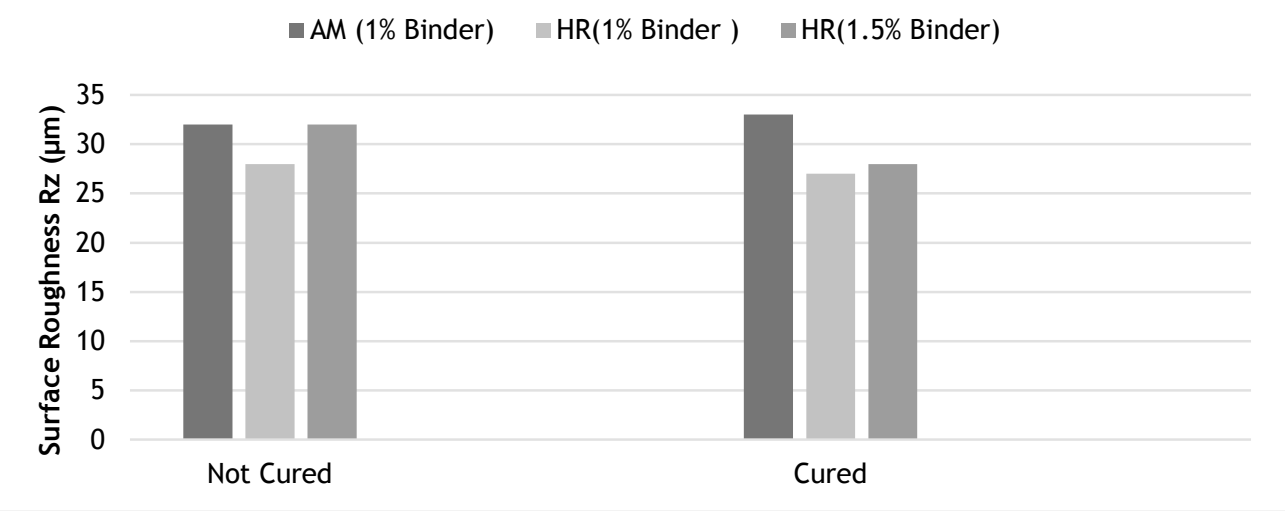

Figure 4: Surface finish of sand specimens

Heat curing does not seem to influence the surface finish of sand specimens materially. The hardness remains constant in the case of $A M$ specimens at $R_{z}$ equal to $33 \mu \mathrm{m}$, while there was a marginal improvement of hardness in the case of HR specimens of 2 per cent to $R_{z}$ equal to $28 \mu \mathrm{m}$.

\subsection{Density}

Figure 5 shows the density test results of compression sand specimens. It can be noted that the AM specimens have a lower density than the HR specimens in the uncured and heat-cured conditions. The AM sand specimens had a density of $1.35 \mathrm{~g} / \mathrm{cm}^{3}$, while the HR samples' densities were measured between 1.55 and $1.51 \mathrm{~g} / \mathrm{cm}^{3}$ respectively for 1 per cent and 1.5 per cent resin addition. This can only be explained by the greater compaction involved in the production of HR specimens than is the case with 3DP printing. Sand compaction is minimal in the case of 3DP printing. This density difference between the AM and HR specimens could also explain the difference in strength observed in Section 3.1. 


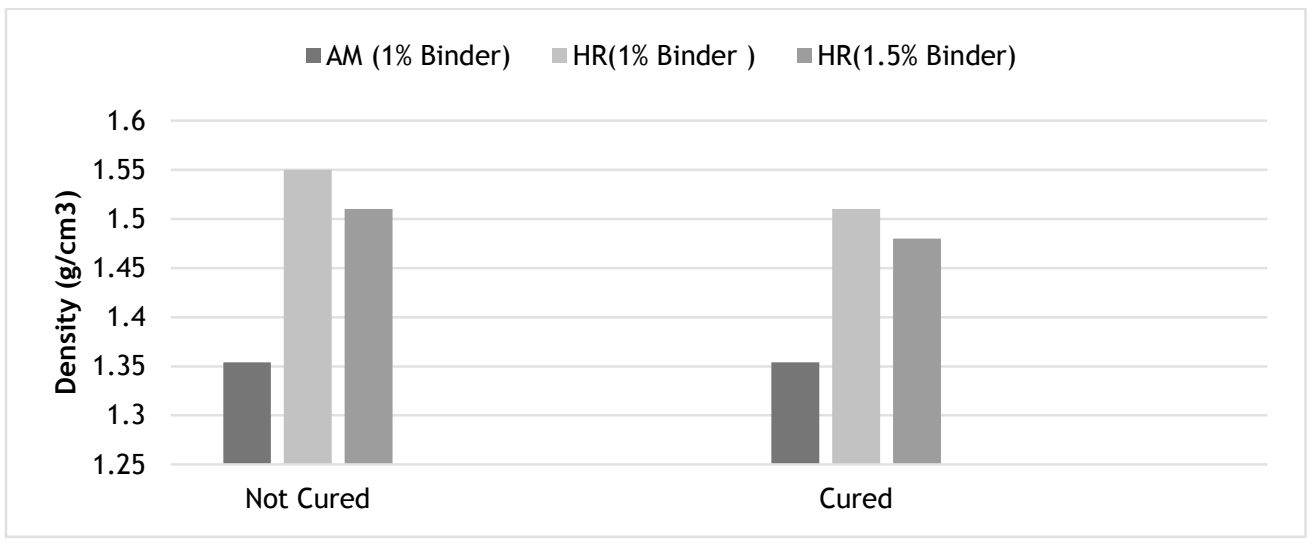

Figure 5: Density of sand specimens

The heat curing did not appear to influence the density of AM specimens as it did in the case of HR specimens. For the latter specimens, an average decrease in density of 2.3 per cent was found. This strange phenomenon could possibly be attributed to a better evaporation of constitutional water of furan-based resin in the case of dense HR sand specimens than happens with AM specimens.

\section{CONCLUSION}

The investigation revealed that there are important differences in foundry properties between AM and conventional HR sand parts. These differences are essentially due to the difference in structure of sand specimens produced by layer-by-layer manufacturing on one side and by compaction on the other. The post-processing of $A M$ sand parts by heating significantly improves tensile and bend strengths, as well as friability, which makes the AM sand parts comparable to conventional HR sand parts with the same resin binder content. It was found, however, that heat had no noticeable effect on the hardness and surface finish of AM sand parts. The latter findings imply that castings produced from $A M$ sand moulds and cores might in general be more prone to metal penetration casting defects, inferior dimensional accuracy, and rough surface finish than those produced in conventional sand moulds.

\section{REFERENCES}

[1] Gardan, J. 2016. Additive manufacturing technologies: State of the art and trends. International Journal of Production Research, 54(10), pp. 3118-3132.

[2] Chhabra, M. and Singh, R. 2011. Rapid casting solutions: A review. Rapid Prototyping Journal, 17(5), pp. 328-350.

[3] Gunther, D., Heymel, B., Gunther, J.F. and Edever, I. 2014. Continuous 3D-printing for additive manufacturing. Rapid Prototyping Journal, 20(4), pp. 320-327.

[4] Mallesham, P. 2015. Overview of rapid prototyping technologies: 3D printing, Journal of Manufacturing Engineering, 10(2), pp. 103-111.

[5] 3D Systems, "Casting, Patterns \& Molds," 2016. [Online]. Available: http: //www.3dsystems.com/solutions/casting-patterns-and-molds. [Accessed 19 July 2016].

[6] ExOne, "Technology Overview," 2016. [Online]. Available: http://www.exone.com/Resources/TechnologyOverview. [Accessed 18 July 2016].

[7] VoxelJet, "The rapid and economical method for sand casting molds," 2016. [Online]. Available: http://www.voxeljet.de/en/services/sand/. [Accessed 15 July 2016].

[8] Budzik, G., Markowski, T., Kozik, B., Przeszlowski, L., Rzucidlo, A., Markowska, O., Zaborniak, M., Dziubek, T., Bernaczek, J., Turek, P., Traciak, J., Cader, M. and Tutak, M. 2014. The application of VoxelJet technology to the rapid prototyping gear cast. Archives of Foundry Engineering, 14(1), pp. 87-90.

[9] W. Gao, Y. Zhang, D. Ramanujan , K. Ramani, Y. Chen, C. B. Williams, C. C. Wang, Y. C. Shin, S. Zhang and P. D. Zavattieri, "The status, challenges, and future of additive manufacturing in engineering," Computer-Aided Design 69, pp. 65-89, 31 December 2015.

[10] Brown, J.R. 2004. Ferrous foundryman's handbook. Burlington: Butterworth-Heinemann.

[11] American Foundry Society. 2006. Mold \& core test handbook. United States of America: American Foundry Society.

[12] Singamneni, S., McKenna, N., Diegel, O., Singh, D., Neitzert, T., St George, J., Choudhury, A.R. and Yarlagadda, P. 2009. Rapid casting: A critical analysis of mould and casting characteristics. Australian Journal of Mechanical Engineering, 7(1), pp. 33-43. 
[13] Snelling, D., Williams, C. and Druschitz, A. 2014. A comparison of binder burnout and mechanical characteristics of printed and chemically bonded sand molds. Retrieved from http://sffsymposium.engr.utexas.edu/sites/default/files/2014-018-Snelling.pdf. Accessed on 21 July 2016.

[14] Snelling, D., Blount, H., Forman, C., Ramsburg, K., Wentzel, A., Williams, C. and Druschitz, A. 2013. The effects of 3D printed molds on metal castings. Retrieved from http://sffsymposium.engr.utexas.edu/Manuscripts/2013/2013-66-Snelling.pdf. Accessed on 21 July 2016.

[15] Bassoli, E. and Atzeni, E. 2009. Direct metal rapid casting: Mechanical optimization and tolerance calculation. Rapid Prototyping Journal, 15(4), pp. 238-243.

[16] Risdale and Risdale Dieter, T. 2009. Foundry sand testing equipment operating instructions. Retrieved from http://www.basrid.co.uk/ridsdale/images/pdf/AFS_OIM.pdf. Accessed on 20 July 2016.

[17] Time High Technology. 2007. Surface roughness tester. Retrieved from http://www.timeinstrument.com/TR100.html. Accessed on 20 July 2016. 